\title{
Aeneolamia Fennah, 1949 (Hemiptera: Cercopidae) attacks pastures in Roraima, with first report in Brazil
}

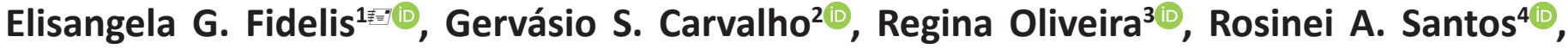 \\ José R. Valério5 ${ }^{50}$
}

${ }^{1}$ Embrapa Recursos Genéticos e Biotecnologia. Parque Estação Biológica, PqEB, Brasília, DF, Brazil. ${ }^{2}$ Pontifícia Universidade Católica do Rio Grande do Sul. Museu de Ciências e Tecnologia da PUCRS, Porto Alegre, RS, Brazil. ${ }^{3}$ Universidade Federal de Roraima and Ministério da Agricultura, Pecuária e Abastecimento, Boa Vista, RR, Brazil. ${ }^{4}$ Empresa Mato-Grossense de Pesquisa, Assistência e Extensão Rural, Santa Terezinha, MT, Brazil. ${ }^{5}$ Embrapa Gado de Corte, Campo Grande, MS, Brazil.

拝-Corresponding author: elisangela.fidelis@gmail.com

\section{Edited by: Leandro D. Geremias}

\section{Received: September 08, 2021. Accepted: December 03, 2021. Published: December 29, 2021.}

Abstract. Spittlebugs (Hemiptera: Cercopidae) are the predominant pasture pests in Brazil, mainly the Amazonia region. Despite frequent reports of attacks by these spittlebugs in Roraima, information on this insect group is scarce. Therefore, we conducted surveys and a population dynamic study in pastures in Roraima from May 2015 to July 2019. We identified the spittlebugs Aeneolamia flavilatera (Urich, 1914) and Aeneolamia reducta montana (Lallemand, 1944). This is the first report of $A$. reducta montana in Brazil, and the first report of $A$. flavilatera attacking pastures. We discuss the possible impacts of these pests on Brazilian agriculture and livestock.

Keywords: Aeneolamia flavilatera, Aeneolamia reducta montana, Brachiaria, spittlebug, Auchenorrhyncha, Cercopoidea.

Beef Cattle production is the second most important sector of the Roraima economy. There are currently approximately 900,000 heads of cattle in the state, and the sector continues to grow (Braga 2016). The expansion of livestock production and the inadequate management of pastures in the Amazon region have led to the degradation of land in these areas (Bendahan 2018; Dias-Filho \& Andrade 2019).

Inadequate pest management is one of the most important factors contributing to pasture degradation in the Amazon (DiasFilho \& Andrade 2019). Spittlebugs (Hemiptera: Cercopidae) are the main pasture insect pests in this region (Teixeira et al. 2019). Adult spittlebugs feed by sucking fluids of the leaves and are responsible for the greatest losses of forage grass, because while feeding, they inject substances that affect the transport of sap and cause tissue death. Spittlebug nymphs feed on the roots of host plants and produce a white foam. The attacked plants have yellow leaves and subsequent necrosis, especially around adult feeding punctures, that lead to death of plants (Wiedijk 1982). In addition, the impact includes decreased dry matter production, increased fiber content, and a consequent reduction in digestibility and support capacity in pastures (Valério 2009).

The main spittlebug species reported in Amazonia are Deois flavopicta (Stal, 1854); Deois incompleta (Walker, 1881); Mahanarva fimbriolata (Stal, 1854); Mahanarva spectabilis (Distant, 1909); Mahanarva tristis (Fabricius, 1803), and Notozulia entreriana (Berg, 1879) (Valério 2009; Teixeira et al. 2019). In Roraima, only Deois (Deois) mourei (Cavichioli \& Sakakibara, 1993) and M. tristis have been reported, but these reports lack details on the hosts, impact, and location (Tolotti et al. 2018). Despite the damage caused by these pests, there are no studies on their population dynamics to date in Roraima. We conducted field surveys and a study of population dynamics in Roraima to better understand the impact of spittlebugs attacking pastures in the region.

Field surveys were conducted in 12 pasture areas in the Roraima municipalities of Alto Alegre, Amajari, Boa Vista, Bonfim, Caracaraí, Iracema, Mucajaí, Rorainópolis, and São João da Baliza from May 2015 to July 2019. Informations regarding all pasture areas are summarized

\section{in Tab. 1.}

For each visited pasture, spittlebugs were sampled using a sweep net (40 cm in diameter) at 12 points in a "zig-zag" sampling pattern. At each point, the net was sweeped 10 times. The collected insects were bagged, labeled, and taken to the Laboratory of Entomology of Embrapa Roraima where they were counted. The adult spittlebugs were stored in flasks with ethanol $70 \%$ for later identification.

A study of population dynamics was also carried out in the municipality of Alto Alegre, Roraima, Brazil, in three pastures from June 2016 to June 2018. Two pasture areas were planted with Brachiaria brizantha (Hochst. ex A. Rich.) Stapf. cv. Marandu (Poaceae) (areas 1 and 2) and the third area was planted with Megathrysus maximus (Jacq.) Simon \& Jacobs cv. Mombaça (Poaceae) (area 3). The areas were sampled monthly, according to method described above. Information about these pasture areas is shown in the Tab. 1.

Spittlebugs collected from both the survey and study areas were identified based on male genitalia. The specimens have been deposited in the Entomological collection of Embrapa Cerrados and in the Museu de Ciências e Tecnologia of the Pontifícia Universidade Católica do Rio Grande do Sul.

Two spittlebug species were found during the field surveys, namely, Aeneolamia flavilatera (Urich, 1914) and Aeneolamia reducta montana Fennah, 1949 (Hemiptera: Cercopidae). Aeneolamia flavilatera was found in Amajari in an area of 400 ha of $B$. brizantha cv. Xaraés and in Rorainópolis in an area of 10 ha of B. brizantha cv. Marandu (Tab. 1). The attack in first area was severe, with browning and death of grasses in around $30 \%$ of the area of 60 ha (Fig. 1E). An average of 29.5 spittlebug/sweep net was observed (Tab. 1).

Only $A$. reducta montana was in Alto Alegre, in the population dynamic study, in Areas 1 and 2 (planted with $B$. brizantha cv. Marandu). In Area 1, A. reducta montana was observed in August 2016 (0.3 spittlebugs/sweep net) and July 2017, while in Area 2, it was observed only in July 2017 (0.4 spittlebugs/sweep net). These occurrences coincide with the rainfall season in the region (Agritempo 2021). This subspecies was also found in Boa Vista, Bonfim, Caracaraí, Iracema, 
Mucajaí, Rorainópolis, and São João da Baliza. The highest population densities were in Bonfim in B. humidicola (2.5 spittlebugs/sweep net) and Rorainópolis (3.3 spittlebugs/sweep net) and São João da Baliza (4.5 spittlebugs/sweep net), in B. brizantha cv. Marandu (Tab. 1).

The nymphs of both species are cream colored and live in the roots of host plants (Fig. 1C), where they produce a characteristic foam, which was observed at the sampling sites (Fig. 1D).

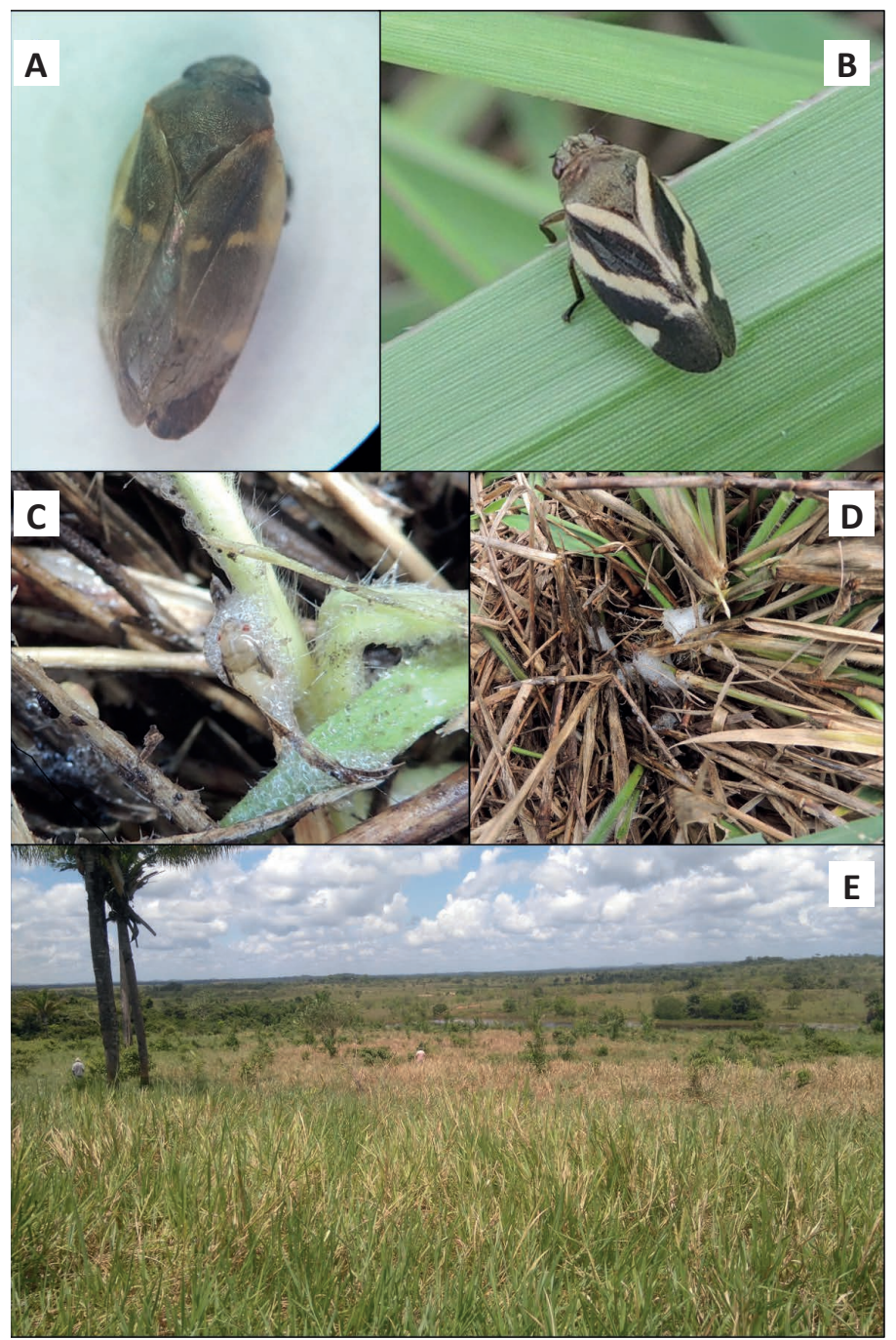

Figure 1. Adults of Aeneolamia flavilatera (A) and Aeneolamia reducta montana (B), nymph (C) and foam (D) of A. reducta montana, and pasture of Brachiaria brizantha $\mathrm{cv}$. Xaraés atacked by $A$. flavilatera $(\mathrm{E})$.

The adult females of both $A$. flavilatera and $A$. reducta montana were approximately $8 \mathrm{~mm}$ long, while males were slightly smaller. The head, pronotum, and scutellum of $A$. flavilatera adults were brown, and their tegmina were light brown, with a light-yellow band on the costal margin that narrowed in half and reached the limit of the posterior third where it terminated in small, weak, light yellow points (Fig. 1A).

The male genitalia of $A$. flavilatera were characterized by a pygofer with a lateral process directed posteriorly and slightly upward, and micro teeth. Below this was found a subgenital plate slightly longer than the basal width, with a widely rounded vertex and very small tooth-shaped spines on the dorsal edge (Fig. 2A). The aedeagus was thin, with very long, thin, and slightly curved fronto-lateral processes inserted more or less in the middle and directed antero-ventrally (Figs. 2B, C). The paramere had an acute apex that was directed backward and outward in a hook-shaped process and covered by tiny dental spines, and a tooth-like dorsal process that was directed posteriorly, located approximately 0.66 from the ventral apode (Fig. 2D) (Carvalho \& Webb 2005).

The head, chest, abdomen, and legs of $A$. reducta montana adults were yellowish-brown, and their tegmina were very dark brown with light yellow spots, one along the anal margin of the clavus, another broad oblique band extended from the costal margin anteriorly, approximately $2 / 10$ of the wing length, up to the apex of the clavus, and a large triangular stain was found on the costal margin at the level of the apex of the clavus (Fig. 1B).
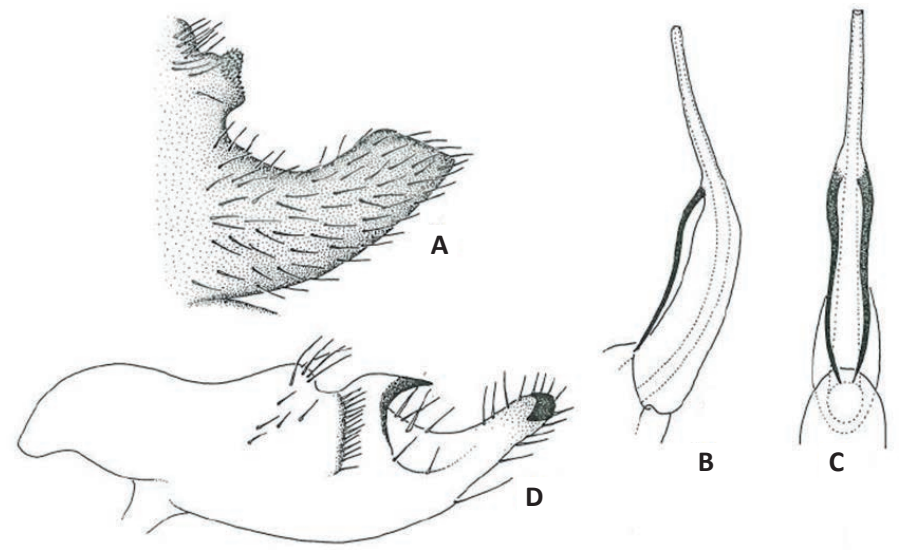

Figure 2. Aeneolamia flavilatera [Fig.230 - Carvalho \& Webb (2005) - modified)] Lateral process of the pygofer and subgenital plaque (A); Aedeagus left side view (B); Aedeagus anterior view (C); Paramere left side view (D).

The male genitalia of $A$. reducta montana were characterized by a pygofer with a lateral process directed posteriorly, and micro teeth. Below this was found a subgenital plate slightly longer than the basal width, with a widely rounded vertex and very small tooth-shaped spines on the dorsal edge (Fig. 3A). The aedeagus was thin, with very long, thin, slightly curved fronto-lateral processes inserted more or less in the middle and directed antero-ventrally (Figs. 3B, C). The paramere had an acute apex that was directed postero-dorsally and covered by small dental spines but was not hook-shaped. It also had a posteriorlydirected dorsal process located approximately 0.66 from the level of the ventral apode and densely covered with small teeth-like spines on the apical side and with an acute, postero-ventrally directed triangular subsidiary process on the ventral side (Fig. 3D) (Carvalho \& Webb 2005).

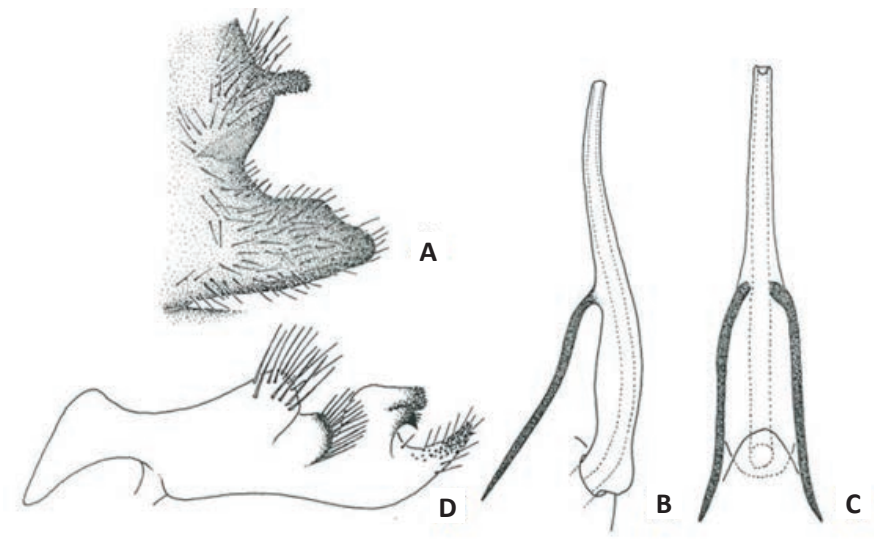

Figure 3. Aeneolamia reducta montana [Fig.225 - Carvalho \& Webb (2005) modified]. Lateral process of the pygofer and subgenital plaque (A); Aedeagus left side view (B); Aedeagus anterior view (C); Paramere left side view (D).

The prevalence of spittlebug species of the Aeneolamia Fennah, 1949 genus in pastures in Roraima is different from that in other Brazilian states, where Deois Fennah, 1949, Mahanarva Distant, 1909, and Notozulia Fennah, 1968 (Valério 2009; Teixeira et al. 2019) are the predominant species. Deois (Deois) mourei and M. tristis, which have been previously reported in Roraima (Tolotti et al. 2018), were not found in this study.

Aeneolamia flavilatera already been collected in the Maracá Island, Roraima, but without details of hosts. This species is an important sugarcane pest in Guyana, French Guiana, Colombia, Suriname, Trinidad, and Venezuela (Wiedijk 1982; Carvalho \& Webb 2005; SoulierPerkins 2021; Cabi 2021) and was originally found in grasses native to savanna areas (Myers 1935; Guagliumi 1962; Wiedijk 1982).

To our knowledge, this is the first report of $A$. reducta montana in Brazil. This subspecies is distributed in Costa Rica, Panama, Colombia, 
Table 1. Municipality, geographic coordinates, pasture, planting area, sampling date and density of Aeneolamia flavilatera e Aeneolamia reducta montana, in Roraima, Brazil.

\begin{tabular}{|c|c|c|c|c|c|c|}
\hline \multirow{2}{*}{ Municipality } & \multirow{2}{*}{ Coordinates } & \multirow{2}{*}{ Pasture } & \multirow{2}{*}{$\begin{array}{l}\text { Area } \\
\text { (ha) }\end{array}$} & \multirow{2}{*}{$\begin{array}{l}\text { Sampling } \\
\text { date }\end{array}$} & \multicolumn{2}{|c|}{ Density } \\
\hline & & & & & A. flavilatera & A. reducta montana \\
\hline \multirow{10}{*}{ Alto Alegre } & $2^{\circ} 50^{\prime} 52.36^{\prime \prime} \mathrm{N}$ & B hrizantha cy Marandu (area 1) & 60 & Aug/2016 & - & 0.3 spittlebugs/sweep net \\
\hline & $61^{\circ} 18^{\prime} 11.55^{\prime \prime} \mathrm{W}$ & 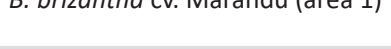 & 00 & Jul/2017 & & 0.4 spittlebugs/sweep net \\
\hline & $\begin{array}{l}2^{\circ} 50^{\prime} 40.09^{\prime \prime} \mathrm{N} \\
61^{\circ} 18^{\prime} 58.72^{\prime \prime} \mathrm{W}\end{array}$ & B. brizantha cv. Marandu (area 2) & 12 & Jul/2017 & - & 0.4 spittlebugs/sweep net \\
\hline & $\begin{array}{l}2^{\circ} 50^{\prime} 37.76^{\prime \prime} \mathrm{N} \\
61^{\circ} 19^{\prime} 7.28^{\prime \prime} \mathrm{W}\end{array}$ & $\begin{array}{l}\text { M. maximum cv. } \\
\text { Mombaça (area 3) }\end{array}$ & 10 & - & - & - \\
\hline & \multirow{3}{*}{$\begin{array}{l}2^{\circ} 47^{\prime} 23.6^{\prime \prime} \mathrm{N} \\
61^{\circ} 17^{\prime} 22.2^{\prime \prime} \mathrm{W}\end{array}$} & \multirow{3}{*}{ B. brizantha cv. Marandu } & \multirow{3}{*}{700} & May/2015 & - & - \\
\hline & & & & Jun/2016 & - & - \\
\hline & & & & Jul/2017 & & 0.4 spittlebugs/sweep net \\
\hline & \multirow{3}{*}{$\begin{array}{l}2^{\circ} 48^{\prime} 13.7^{\prime \prime} \mathrm{N} \\
61^{\circ} 16^{\prime} 58.9^{\prime \prime} \mathrm{W}\end{array}$} & \multirow{3}{*}{ B. brizantha cv. Piatã } & \multirow{3}{*}{100} & May/2015 & - & - \\
\hline & & & & Jun/2016 & - & - \\
\hline & & & & Jul/2017 & - & - \\
\hline Amajari & $\begin{array}{l}3^{\circ} 30^{\prime} 04.5^{\prime \prime} \mathrm{N} \\
61^{\circ} 29^{\prime} 57.6^{\prime \prime} \mathrm{W}\end{array}$ & B. brizantha cv. Xaraés & 400 & Sept/2017 & 29.5 spittlebugs/sweep net & - \\
\hline \multirow{2}{*}{ Boa Vista } & $\begin{array}{l}2^{\circ} 40^{\prime} 01.9^{\prime \prime} \mathrm{N} \\
60^{\circ} 51^{\prime} 07.8^{\prime \prime} \mathrm{W}\end{array}$ & $\begin{array}{l}\text { B. ruziziensis, B. brizantha. } \\
\text { cvs. Piatã e Marandu }\end{array}$ & 1 & $\begin{array}{l}\text { Jun/2016 } \\
\text { and } 2017\end{array}$ & & Found. but not measured \\
\hline & $\begin{array}{l}2^{\circ} 29^{\prime} 10.1^{\prime \prime} \mathrm{N} \\
60^{\circ} 53^{\prime} 00.3^{\prime \prime} \mathrm{W}\end{array}$ & B. ruziziensis & 55 & Jul/2018 & - & 0.5 spittlebugs/sweep net \\
\hline \multirow{2}{*}{ Bonfim } & \multirow{2}{*}{$\begin{array}{l}2^{\circ} 58^{\prime} 46.46^{\prime \prime} \mathrm{N} \\
60^{\circ} 21^{\prime} 49.12^{\prime \prime} \mathrm{W}\end{array}$} & B. brizantha cv. Marandu & 60 & May/2016 & - & 0.5 spittlebugs/sweep net \\
\hline & & B. humidicola & 60 & May/2016 & - & 2.5 spittlebugs/sweep net \\
\hline Caracaraí & $\begin{array}{l}1^{\circ} 28^{\prime} 43.9^{\prime \prime} \mathrm{N} \\
60^{\circ} 48^{\prime} 58.9^{\prime \prime} \mathrm{W}\end{array}$ & B. brizantha cv. Marandu & 150 & May/2016 & - & Found. but not measured \\
\hline Iracema & $\begin{array}{l}2^{\circ} 23^{\prime} 43.0^{\prime \prime} \mathrm{N} \\
60^{\circ} 58^{\prime} 47.3^{\prime \prime} \mathrm{W}\end{array}$ & B. ruziziensis & 60 & Jun/2017 & - & Found. but not measured \\
\hline Mucajaí & $\begin{array}{l}2^{\circ} 23^{\prime} 43.0^{\prime \prime} \mathrm{N} \\
60^{\circ} 58^{\prime} 47.3^{\prime \prime} \mathrm{W}\end{array}$ & $\begin{array}{l}\text { B. ruziziensis, B. brizantha } \\
\text { cv. Marandu }\end{array}$ & 1 & $\begin{array}{l}\text { Jun/2016 } \\
\text { and } 2017\end{array}$ & - & Found. but not measured \\
\hline \multirow{2}{*}{ Rorainópolis } & $\begin{array}{l}0^{\circ} 06^{\prime} 25.5^{\prime \prime} \mathrm{N} \\
60^{\circ} 35^{\prime} 11.2^{\prime \prime} \mathrm{W}\end{array}$ & B. brizantha cv. Marandu & 1.5 & Jul/2019 & - & 3.3 spittlebugs/sweep net \\
\hline & $\begin{array}{c}0^{\circ} 15^{\prime} 30^{\prime \prime} \mathrm{N} \\
60^{\circ} 31^{\prime} 01.3^{\prime \prime} \mathrm{W}\end{array}$ & B. brizantha cv. Marandu & 10 & Jul/2019 & 2.0 spittlebugs/sweep net & \\
\hline $\begin{array}{l}\text { São João } \\
\text { da Baliza }\end{array}$ & $\begin{array}{c}0^{\circ} 55^{\prime} 40.3^{\prime \prime} \mathrm{N} \\
59^{\circ} 55^{\prime} 13.0^{\prime \prime} \mathrm{W}\end{array}$ & B. brizantha cv. Marandu & 5 & Jul/2019 & - & 4.5 spittlebugs/sweep net \\
\hline
\end{tabular}

and Venezuela, where it is an important pasture pest, especially to grasses belonging to the genus Brachiaria (Peck 2001; Peck et al. 2002; Carvalho \& Webb 2005). In Colombia, the Brachiaria breeding program at the International Center for Tropical Agriculture aims to obtain cultivars of Brachiaria spp. that are resistant to this subspecies of spittlebugs (Miles et al. 2006; Cardona et al. 2010). Infestations of A. reducta montana have also been reported in Bothriochloa pertusa (L.) A. Camus, Dichanthium aristatum (Poir.) C.E. Hubb. and Panicum fasciculatum Sw. (Poaceae) in Colombia (Peck et al. 2002), and sugarcane [Saccharum officinarum L. (Poaceae)] in Panama (Guagliumi 1962; apud Thompson \& Gonzales 2005).

Severe $A$. reducta montana attacks were observed in $B$. humidicola, in Bonfim and in B. brizantha cv. Xaraés, in Amajari. Producers on these farms reported that attacks by this spittlebug species occurred frequently at the end of rainy season, causing pasture degradation. This was also observed in our study areas in Alto Alegre.

Forage grass resistance is the most suitable method for managing spittlebug populations in pasture ecosystems (Auad et al. 2007; Valério 2009). The Embrapa tropical forage breeding program aims to obtain forage grass cultivars with a high level of antibiosis against the spittlebug genera Deois, Mahanarva, and Notozulia (Auad et al. 2007; Valério 2009; Gusmão et al. 2016; Ferreira et al. 2019). Given the severe damage caused by $A$. flavilatera and $A$. reducta montana in pastures in Roraima, these insects should be included in the Embrapa tropical forage breeding program for the indication of grass in this state.

Bioecology studies of these pests are also needed to better understand the damage, host plants, and population dynamics. In addition, phytosanitary measures should be adopted to avoid the dispersion of $A$. flavilatera and $A$. reducta montana to other Brazilian states.

\section{Acknowledgements}

The authors thank to Empresa Brasileira de Pesquisa Agropecuária - Embrapa for financial support (Grant No. 13.16.05.028.00.00), and Coordenação de Aperfeiçoamento de Pessoal de Nível Superior (CAPES) (Finance Code 001).

\section{Authors' Contributions}

EGF planned and designed the study, collected field data and wrote the manuscript. GSC identified the Cercopidae and provided taxonomic information about the species. RO collected field data and analyzed the samples in laboratory. RAS reviewed the manuscript. JRV guided and mediated contacts culminating in the species identification and reviewed the manuscript. All authors read, revised, and approved the manuscript. 


\section{References}

Agritempo (2021) Sistema de Monitoramento Agrometeorológico. http://www.agritempo.gov.br. Access on: 16.iii.2021.

Auad, A. M.; Simoes, A. D.; Pereira, A. V.; Braga, A. L. F; Souza-Sobrinho, F.; Lédo, F.J.S.; Paula-Moraes, S. V.; Oliveira, A. S.; Ferreira, R. B. (2007) Seleção ao de genótipos de capim-elefante quanto a resistência a cigarrinha das pastagens. Pesquisa Agropecuária Brasileira, 42: 1077-1081. doi: 10.1590/S0100-204X2007000800003

Bendahan, A. B.; Poccard-Chapuis, R.; Medeiros, R. D. De; Costa, N. De L.; Tourrand, J. F. (2018) Management and labour in an integrated crop-livestock-forestry system in Roraima, Brazilian Amazonia. Cahiers Agricultures, 27(2): 1-7. doi: 10.1051/cagri/2018014

Braga, R. M. (2016) A agricultura e a pecuária na história de Roraima. Boa Vista: PoloBooks.

Cabi (2021) Aeneolamia flavilatera (yellow-sided froghopper). Invasive Species Compendium. https://www.cabi.org/isc/datasheet/3421. Acesss on: 9.ii.2021.

Cardona, C.; Miles, J. W.; Zuñiga, E.; Sotelo G. (2010) Independence of resistance in Brachiaria spp. to nymphs or to adult spittlebugs (Hemiptera: Cercopidae): implications for breeding for resistance. Journal of Economic Entomology, 103(5): 1860-1865. doi: 10.1603/ EC10004

Carvalho G.; Webb M. (2005) Cercopid spittle bugs of the new world. Sofia: Pensoft.

Cavichioli, R. R.; Sakakibara, A. (1993) Deois Fennah, descrição de uma espécie nova e notas taxonômicas (Homoptera, Cercopidae, Tomaspidinae). Revista Brasileira de Zoologia, 10: 747-750.

Dias-Filho, M. B.; Andrade, C. M. S. (2019) Recuperação de pastagens degradadas na Amazônia. Brasília: Embrapa.

Ferreira, R. C. U.; Lara, L. A. C.; Chiari, L.; Barrios, S. C. L.; Valle, C. B.; Valério, J. R.; Torres, F. Z. V.; Garcia A. A. F.; Souza A. P. (2019) Genetic mapping with allele dosage information in tetraploid Urochloa decumbens (Stapf) R. D. Webster reveals insights into spittlebug (Notozulia entreriana Berg) resistance. Frontiers in Plant Science, 10(92): 1-16. doi: 10.3389/fpls.2019.00092

Guagliumi, P. (1962) Las plagas de la cana de azücar en Venezuela. Maracay: Ministerio de Agricultura y Cría, Centro de Investigaciones Agronomicas.

Gusmão, M. R.; Valério, J. R.; Matta, F. P.; Souza, F. H. D.; Vigna, B. B. Z.; Fávero, A. P.; Barioni Jr, W.; Inácio, G. R. (2016) Warm-season (C4) turfgrass genotypes resistant to spittlebugs (Hemiptera: Cercopidae). Journal of Economic Entomology, 109: 1914-1921. doi: 10.1093/jee/tow135

Miles, J. W.; Cardona, C.; Sotelo, G. (2006) Recurrent selection in a synthetic brachiariagrass population improves resistance to three spittlebug species. Crop Science, 46: 1088-1093. doi: 10.2135/ cropsci2005.06-0101

Myers, J. G. (1935) The ecological distribution of some South American froghoppers of the genus Tomaspis (Horn., Cercopidae). Tropical Agriculture, 12(5): 114-118.

Peck, D.C. (2001) Diversidad y distribución geográfica del salivazo (Homoptera: Cercopidae) asociado con gramíneas en Colombia y Ecuador. Revista Colombiana de Entomología, 27: 129-136.

Peck, D.C.; Pérez, A.M.; Medina, J.W.; Rojas, J.; Barrios. M. (2002) Fluctuación poblacional y enemigos naturales de Aeneolamia reducta en la Costa Caribe de Colombia. Pasturas Tropicales, 24: 27-38.

Soulier-Perkins, A. (2021) COOL - Cercopoidea Organised On Line. http://hemiptera-databases.org/cool/. Access on: 9.ii.2021.

Teixeira, C. A. D.; Costa, J. N. M.; Fidelis, E. G.; Bendahan, A. B. (2019) Manejo de insetos-praga em pastagens na Amazônia. In: DiasFilho, M. B.; Andrade, C. M. S. (Ed.). Recuperação de pastagens degradadas na Amazônia, pp. 253-288. Brasília: Embrapa.

Thompson, V.; León González, R. (2005) La identificación y distribución de los salivazos de la caña de azúcar y los pastos (Homoptera: Cercopidae) en Costa Rica. Manejo Integrado de Plagas y Agroecología, 75, 43 - 51.
Tolotti, A.; Azevedo-Filho, W. S.; Valiati, V. H; Carvalho, G. S.; Valério, J. R. (2018) Cigarrinhas-das-pastagens em gramíneas forrageiras no Brasil. Porto Alegre: Evangraf.

Valério, J. R. (2009) Cigarrinhas-das-pastagens. Campo Grande: Embrapa Gado de Corte. (Documentos, 179). https://www. infoteca.cnptia.embrapa.br/handle/doc/853370. Access on: 9.iv. 2021.

Wiedijk, F. (1982) Variability in the occurrence of the sugar cane froghopper, Aeneolamia flavilatera (Homoptera: Cercopidae), on sugar estates in Guyana and Surinam. Mededelingen Landbouwhogeschool Wageningen, 7: 1-55. 